\section{Preemergence Herbicide Effects on Hybrid Bermudagrass Root Architecture and Establishment}

\author{
Erick G. Begitschke, ${ }^{1,6}$ James D. McCurdy ${ }^{2}$, Te-Ming Tseng ${ }^{2}$, \\ T. Casey Barickman ${ }^{2}$, and Barry R. Stewart ${ }^{3}$ \\ Department of Plant and Soil Sciences, Mississippi State University, \\ Starkville, MS 39762
}

\author{
Christian M. Baldwin ${ }^{4}$ \\ Scott's Miracle-Gro Company, Marysville, $\mathrm{OH} 43040$
}

\author{
Michael P. Richard ${ }^{5}$ \\ Department of Plant and Soil Sciences, Mississippi State University, \\ Starkville, MS 39762
}

\section{Maria Tomaso-Peterson ${ }^{3}$ \\ Department of Biochemistry, Molecular Biology, Entomology, and Plant Pathology, Mississippi State University, Starkville, MS 39762}

Additional index words. Cynodon dactylon Pers. $\times$ Cynodon transvaalensis Burtt-Davy, sod production, turfgrass, turf, golf course, athletic field

\begin{abstract}
Preemergence herbicides generally have a negative effect on hybrid bermudagrass [Cynodon dactylon (L.) Pers. $\times$ C. transvaalensis Burtt-Davy] establishment. However, little is known about the effect they have on root architecture and development. Research was conducted to determine the effects of commonly used preemergence herbicides on 'Latitude 36' hybrid bermudagrass root architecture and establishment. The experiment was conducted in a climate-controlled greenhouse maintained at $26{ }^{\circ} \mathrm{C}$ day/night temperature at Mississippi State University in Starkville, MS, from Apr. 2016 to June 2016 and repeated from July 2016 to Sept. 2016. Hybrid bermudagrass plugs $\left(31.6 \mathrm{~cm}^{2}\right)$ were planted in $126-\mathrm{cm}^{2}$ pots $\left(1120 \mathrm{~cm}^{3}\right)$ and preemergence herbicide treatments were applied $1 \mathrm{~d}$ after planting at the recommended labeled rate for each herbicide. Preemergence herbicide treatments included atrazine, atrazine $+S$-metolachlor, dithiopyr, flumioxazin, indaziflam, liquid and granular applied oxadiazon, $S$-metolachlor, pendimethalin, prodiamine, and simazine. Treatments were arranged in a completely randomized design with four replications. Plugs treated with indaziflam and liquid applied oxadiazon failed to achieve $50 \%$ hybrid bermudagrass cover by the end of the experiment. Of the remaining herbicide treatments, all herbicides other than granular applied oxadiazon and atrazine increased the number of days required to reach $50 \%$

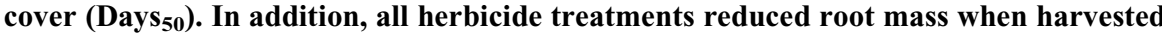
6 weeks after treatment (WAT) relative to the nontreated. By $10 \mathrm{WAT}$, all treatments reduced root mass in run 1 , but during run 2 , only prodiamine, pendimethalin, simazine, atrazine $+S$-metolachlor, liquid applied oxadiazon, and indaziflam reduced dry root mass compared with the nontreated. At 4 WAT, all treatments other than simazine and granular applied oxadiazon reduced root length when compared with the nontreated. By 10 WAT, only dithiopyr, $S$-metolachlor alone, and indaziflam reduced root length when compared with the nontreated. No differences were detected in the total amounts of nonstarch nonstructural carbohydrates (TNSC) within the roots in either run of the experiment. Results suggest that indaziflam, dithiopyr, and S-metolachlor are not safe on newly established hybrid bermudagrass and should be avoided during establishment. For all other treatments, hybrid bermudagrass roots were able to recover from initial herbicidal injury by 10 WAT; however, future research should evaluate tensile strength of treated sod.
\end{abstract}

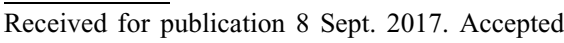
for publication 30 Dec. 2017.

${ }^{1}$ Graduate Research Assistant.

${ }^{2}$ Assistant Professor.

${ }^{3}$ Associate Professor.

${ }^{4}$ Turfgrass Scientist.

${ }^{5}$ Extension Associate.

${ }^{6}$ Corresponding author. E-mail: ebegitsc@gmail. com.
}

Bermudagrass (Cynodon spp.) is commonly produced as sod throughout the southern United States and other temperate or transition climate zones throughout the world, with most of the growers producing vegetatively propagated hybrid bermudagrass $[C$. dactylon (L.) Pers. $\times C$. trans vaalensis Burtt-Davy] varieties (McCalla et al., 2008). To meet the demand for quality sod, producers must account for the aesthetic, harvesting, and establishment characteristics of the hybrid bermudagrass (Sharpe et al., 1989). Annual grassy weeds, such as crabgrass (Digitaria spp.) and goosegrass [Eleusine indica (L.) Gaertn.], commonly germinate during hybrid bermudagrass establishment, which can reduce turfgrass quality and harvesting characteristics (Fishel and Coats, 1994; Johnson, 1996). Many sod producers use preemergence herbicides, such as prodiamine, pendimethalin, and dithiopyr, to control these grassy weeds. However, many preemergence herbicides may hinder root growth and establishment of hybrid bermudagrass (Bingham and Hall, 1985; Brosnan et al., 2014; Fagerness et al., 2002). Prodiamine and pendimethalin are mitotic-inhibiting herbicides that commonly cause malformed and stubby roots on hybrid bermudagrass (Vaughn and Vaughn, 1990; Weber, 1990). Fishel and Coats (1994) determined that prodiamine, pendimethalin, and dithiopyr also increased the number of roots that were considered abnormal (less than $2.5 \mathrm{~cm}$, lacked secondary root formation, or were swollen). In the same study, labeled rates of dithiopyr and prodiamine significantly reduced root fresh weight of hybrid bermudagrass plugs when compared with pendimethalin and oxadiazon (Fishel and Coats, 1994).

Producing new roots quickly is critical to establishing hybrid bermudagrass sod. For example, Bingham and Hall (1985) determined that 'Tifway' hybrid bermudagrass was tolerant to oxadiazon because the herbicide did not negatively affect shoot or root growth throughout establishment. However, Bingham and Schmidt (1983) determined that a high rate of oxadiazon $\left(6.7 \mathrm{~kg} \cdot \mathrm{ha}^{-1}\right)$ slightly reduced hybrid bermudagrass root growth, although adequate root growth was apparent for proper plant function. McCullough et al. (2012) determined that $S$-metolachlor (1.1 and $2.2 \mathrm{~kg}$ a.i./ha) and oxadiazon (1.1, 2.2 , and $4.4 \mathrm{~kg}$ a.i./ha) did not reduce hybrid bermudagrass cover relative to the nontreated 8 WAT. However, the higher rate of $S$-metolachlor (4.4 kg a.i./ha) did significantly reduce hybrid bermudagrass cover measured at the same time interval. Brosnan et al. (2014) determined that pendimethalin (3.36 kg a.i./ha), dithiopyr $(0.56 \mathrm{~kg}$ a.i./ha), prodiamine (0.6 kg a.i./ha), oxadiazon (3.36 kg a.i./ha), prodiamine + sulfentrazone $(0.84+0.41 \mathrm{~kg}$ a.i./ha), dimethenamid- $P$ (1.68 kg a.i./ha), and indaziflam $(0.03$ and $0.05 \mathrm{~kg}$ a.i./ha) all increased the days to reach $50 \%$ hybrid bermudagrass cover when compared with the nontreated. However, only the two rates of indaziflam $(0.03$ and $0.05 \mathrm{~kg}$ a.i./ha) reduced sod tensile strength compared with the nontreated when harvested $377 \mathrm{~d}$ after sprigging.

Preemergence herbicides may affect the amounts of nonstructural carbohydrates within the roots, which may have an impact on plant function, transplant success, and spring green-up (Macolino et al., 2010; Schiavon et al., 2016). White (1973) describes nonstructural carbohydrates as the total amount of reducing and nonreducing sugars, as well 
as fructosans and starch. The levels of these sugars may be used to measure the physiological stresses experienced by the plant, including possible herbicidal injury (Hull, 1992; Sheffer et al., 1979). However, research to determine the amount of nonstructural carbohydrates within hybrid bermudagrass roots in response to herbicide application is lacking. Therefore, research was conducted to determine the effects of preemergence herbicides commonly used on sod farms on hybrid bermudagrass root architecture and to provide some insight into the effects of these preemergence herbicides on the amounts of nonstructural carbohydrates within those roots.

\section{Materials and Methods}

Research was conducted in a climatecontrolled greenhouse maintained at $26{ }^{\circ} \mathrm{C}$ day/night temperature at Mississippi State University (Starkville, MS) from Apr. 2016 to June 2016 and repeated from July 2016 to Sept. 2016. The experimental design was a complete randomization with four replications. Herbicide treatments are listed in Table 1. Each replication also included a nontreated control. 'Latitude 36' hybrid bermudagrass plugs $\left(31.6 \mathrm{~cm}^{2}\right)$ were planted in a native Marietta silt loam (fine-loamy, siliceous, active, and Fluvaquentic Eutrudepts) soil in $126-\mathrm{cm}^{2}$ pots $\left(1120 \mathrm{~cm}^{3}\right)$. Plugs were cut from sod grown in a similar native soil at the R. R. Foil Plant Science Research Center located in Starkville, MS. The sod from which the plugs were taken was established from sprigs $\approx 1$ year before harvest. Sod was harvested with a walk-behind Ryan Jr. Sod Cutter (CGC Inc., Johnson Creek, WI) to a depth of $2 \mathrm{~cm}$ before removal of plugs and subsequent transplanting to pots. Authors are aware that hybrid bermudagrass is generally planted as sprigs; however, plugs cut from sod were used to promote uniformity among experimental units in terms of planting depth, node density, and size. It is likely that these plugs received significant carbohydrate contributions from the ongoing photosynthesis of the full leaf canopy, which may have influenced root carbohydrate pools and root development. Therefore, only the new root growth below the original plug was harvested for root architecture and carbohydrate analysis.

Preemergence herbicide treatments were applied broadcast exactly $1 \mathrm{~d}$ after planting with a $\mathrm{CO}_{2}$-powered backpack sprayer calibrated to deliver $374 \mathrm{~L} \cdot \mathrm{ha}^{-1}$ using 11,004 flatfan spray nozzles (TeeJet, Spraying Systems Co., Roswell, GA). The pots remained outside the greenhouse for $3 \mathrm{~h}$ after herbicide application to allow for adequate penetration into the leaf surface before being placed into the greenhouse and irrigated over the top with $5 \mathrm{~mm}$ water over the top using a hose and spray nozzle attachment. The plugs were then irrigated with $3 \mathrm{~mm}$ water twice daily until completion of the study. All pots were fertilized using Miracle-Gro ${ }^{\circledR}$ Water Soluble All Purpose Plant Food fertilizer (24-8-16, $49 \mathrm{~kg}$ nitrogen $(\mathrm{N}) / \mathrm{ha}$; Scott's Miracle-Gro Products Inc., Port Washington, NY) 1 and 4 WAT for both runs of the experiment. Turf was mown weekly to a height of $4 \mathrm{~cm}$ throughout the experiment with a stationary mounted reel mower.

Hybrid bermudagrass cover. Hybrid bermudagrass cover was measured weekly throughout the course of the experiment using digital image analysis similar to Karcher and Richardson (2003) and Richardson et al. (2001). Digital images were taken using a $0.31 \mathrm{~m}^{2}$ light box containing four helical 10 -W soft white lamps (GE Lighting, Cleveland, $\mathrm{OH})$. Images were captured with a digital camera (Nikon D90 with AF-S DX NIKKOR 18-105 mm attachable lens; Nikon Inc., Melville, NY) capable of capturing 12.3 million pixels per image. The digital camera was properly white-balanced, along with settings as follows: 1/60 aperture size, $5.6 \mathrm{f}$-stop, 5500 shutter speed, and 500 Internation Stadards Organization (ISO) sensitivity. The photos were analyzed using the Edit Cover Analysis macro within SigmaScan Pro (Systat Software, San Jose, CA) software to determine percent hybrid bermudagrass cover. Percent cover was determined by the ratio of green pixels within a hue range of 42 to $100^{\circ}$ and saturation values between $3 \%$ and $100 \%$ vs. the total number of pixels of the image (424,800 pixels). To account for fitting a round pot within a square image, a neon pink foam board background (Elmer's Products, Inc., Westerville, $\mathrm{OH}$ ) was cut to the size of the pot to provide consistency between images. A calibration image of a $100 \%$ hybrid bermudagrass-covered pot was used to artificially construct the estimates of percent cover.

Root architecture. The plugs were washed free of soil and all new root growth below the original plug were harvested and weighed 4 , 6 , and 10 WAT. Roots were immediately placed in a standard freezer $\left(-18^{\circ} \mathrm{C}\right)$ for $\approx 24 \mathrm{~h}$. The root samples were then placed in $50-\mathrm{mL}$ conical centrifuge tubes (Thermo Fisher Scientific Inc., Waltham, MA) along with a 5\% sodium hexametaphosphate (The Chemistry Store.com, Cayce, SC) dispersing solution and were lightly shaken overnight. The samples were then spread throughout waterproof trays and scanned in black and white at 315 dots/cm (0.032-mm pixel size) using an STD4800 scanner for analysis within WinRHIZO Pro (Regent Instruments Inc., Sainte-Foy, Quebec City, Canada) software to quantify total root length, root surface area, and average root diameter.

Carbohydrate analysis. Separate experimental units were planted to determine the dry root mass and amount of nonstarch nonstructural carbohydrates within the roots. Roots were harvested 6 and 10 WAT, washed free of soil, and all new root growth below the original plug was harvested. The root samples were immediately placed in a $-80{ }^{\circ} \mathrm{C}$ freezer after harvesting and remained in the freezer for at least $24 \mathrm{~h}$. The roots were then placed in a freeze dryer for another $24 \mathrm{~h}$. After removal from the freeze dryer, a single silica desiccant bag was placed inside each sample bag to prevent rehydration. The root samples were weighed to determine dry weight before being ground using a common tobacco grinder.

The carbohydrate analysis procedure was similar to that of Barickman et al. (2017) with a few minor adjustments to account for the size of the subsamples. A $0.05 \mathrm{~g}$ subsample was extracted from each root sample in a $15-\mathrm{mL}$ test tube by adding $3 \mathrm{~mL}$ doubledistilled water $\left(\mathrm{ddH}_{2} \mathrm{O}\right)$ and vortexed for $15 \mathrm{~min}$. The root samples were then centrifuged for $10 \mathrm{~min}$ at 3.0 relative centrifugal

Table 1. Research was conducted in a climate-controlled greenhouse at Mississippi State University to determine the effects of preemergence herbicides on 'Latitude 36' hybrid bermudagrass root growth and grow-in.

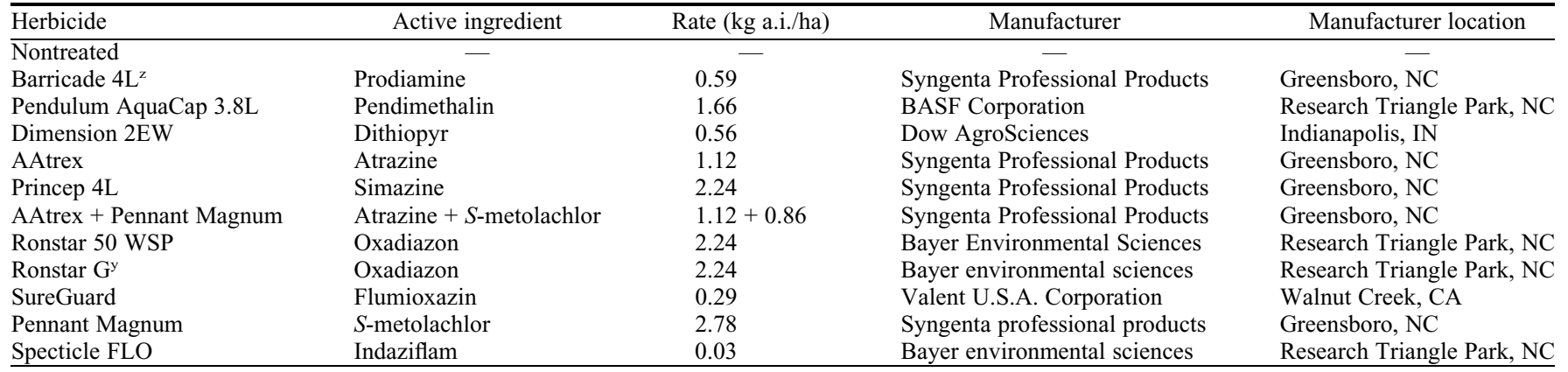

${ }^{\mathrm{z}}$ Liquid formulations of preemergence herbicide treatments were applied using a $\mathrm{CO}_{2}$-powered backpack sprayer calibrated to $374 \mathrm{~L}$.ha ${ }^{-1}$ using 11,004 flat-fan spray nozzles.

${ }^{\mathrm{y}}$ Granular formulation of oxadiazon was applied broadcast by hand.

$\mathrm{L}=$ liquid; $\mathrm{EW}=$ emulsion in water; $\mathrm{WSP}=$ water-soluble powder; $\mathrm{FLO}=$ flowable. 
force (RCF) and $0.5 \mathrm{~mL}$ of the supernatant was extracted into another $15-\mathrm{mL}$ test tube. After transferring, $0.7 \mathrm{~mL}$ acetonitrile was added, mixed by inversion, and stored at room temperature for at least $30 \mathrm{~min}$. These samples were centrifuged again at 3.0 RCF for $10 \mathrm{~min}$ and another $0.5 \mathrm{~mL}$ of supernatant was extracted into a $15-\mathrm{mL}$ test tube. The samples were then placed in a dry bath until complete evaporation. Once the drying process was complete, the samples were rehydrated with $0.5 \mathrm{~mL}$ of $75 \%$ acetonitrile to $25 \% \mathrm{ddH}_{2} \mathrm{O}(\mathrm{v} / \mathrm{v})$ solution and filtered using a $0.2-\mu \mathrm{m}$ syringe filter. The samples were then placed in $2-\mathrm{mL}$ high-performance liquid chromatography (HPLC) vials for analysis. The analysis was performed using the same Agilent Technologies 1260 Infinity series HPLC with an evaporative light scattering detector (Agilent Technologies, Palo Alto, CA) as described by Barickman et al. (2017). All samples were analyzed for the amounts of sucrose, fructose, and glucose. The sum of these three sugars is also presented as the total nonstarch nonstructural carbohydrates (TNSC) within the roots.

Statistical analysis. Hybrid bermudagrass cover data were log transformed and subject to a nonlinear sigmoidal variable slope regression model to determine time to $50 \%$ cover:

$$
\% \text { Cover }=\frac{100}{1+10^{\left[\left(\text {Days }_{50}-\text { DAT }\right) \text { slope }\right]},}
$$

where \%Cover represents the percentage green cover determined by SigmaScan Pro (Systat Software, Inc., San Jose, CA), DAT is days after treatment, and Days ${ }_{50}$ represents the logarithmic equivalent for the regression estimate of days to reach $50 \%$ hybrid bermudagrass cover, and slope estimates indicate how quickly hybrid bermudagrass cover increased over time. All nonlinear regression analyses were performed using GraphPad Prism 6 software (GraphPad Software, San Diego, CA). Differences between regression estimates were based on predicted $95 \%$ confidence intervals. The maximum percentage cover value measured during the course of the experiment is also presented for purposes of comparison and discussion. Dry root mass, carbohydrate analysis, root length, root surface area, and average root diameter data were subject to analysis of variance (ANOVA) $(\alpha=0.05)$ in SAS Proc ANOVA (Version 9.4; SAS Institute Inc., Cary, NC), and Fisher's protected least significant difference, provided the means separation between treatments.

\section{Results and Discussion}

Hybrid bermudagrass cover, root architecture, and amount of nonstructural carbohydrates within the roots differed because of herbicide treatment. Only dry root mass measured 10 WAT differed because of run of the experiment. All other data were able to be pooled across both runs for purposes of statistical analysis. Pooled results are presented separately by response variable for root architecture and carbohydrate data are presented separately by harvest timing.

\section{Hybrid bermudagrass cover}

Hybrid bermudagrass plugs treated with indaziflam and liquid applied oxadiazon failed to reach $50 \%$ cover during the course of the experiment. Among the remaining herbicide treatments, all but atrazine and granular applied oxadiazon increased Days 50 when compared with the nontreated (Table 2). Days $_{50}$ were lowest for pendimethalin, dithiopyr, simazine, and flumioxazin and greatest with prodiamine, atrazine $+S$-metolachlor, and $S$-metolachlor alone. The trends observed within Days 50 seemed to correlate with the maximum percentage cover value achieved, with the same herbicides that increased Days 50 also having a lower maximum cover value.

\section{Root architecture}

Dry root mass. Dry root mass was recorded 6 and 10 WAT. Root growth was insufficient for proper freeze drying at the earliest timing, 4 WAT. Dry root mass was pooled across experimental runs for the
6 WAT timing; however, a significant difference was detected in the dry root mass harvested $10 \mathrm{WAT}$. Therefore, the $10 \mathrm{WAT}$ data for each run of the experiment are presented separately.

All herbicide treatments reduced dry root mass harvested 6 WAT relative to the nontreated (Table 3). Similarly, treatments reduced dry root mass in run 1 when roots were harvested $10 \mathrm{WAT}$. During run 2, only prodiamine, pendimethalin, simazine, atrazine + $S$-metolachlor, liquid applied oxadiazon, and indaziflam reduced dry root mass compared with the nontreated when harvested 10 WAT. Interestingly, flumioxazin increased dry root mass when harvested 10 WAT in run 2 when compared with every treatment other than atrazine, including the nontreated.

Root length. When harvested 4 WAT, every herbicide treatment other than simazine and granular applied oxadiazon reduced root length when compared with the nontreated (Table 4). By 6 WAT, only $S$-metolachlor

Table 2. Predicted number of days to reach $50 \%$ hybrid bermudagrass cover (Days ${ }_{50}$ ) based on nonlinear sigmoidal variable slope regression estimators

\begin{tabular}{|c|c|c|c|c|c|c|}
\hline \multirow[b]{3}{*}{ Herbicide } & \multirow{3}{*}{$\begin{array}{c}\text { Rate } \\
\text { (kg a.i./ha) }\end{array}$} & & \multicolumn{2}{|c|}{ Days $_{50} 95 \%$ CI } & \multirow[b]{3}{*}{$r^{2}$} & \multirow{3}{*}{$\begin{array}{c}\text { Max } \\
\operatorname{cover}^{2}(\%)\end{array}$} \\
\hline & & $\underline{\text { Days }_{50}}$ & Lower & Higher & & \\
\hline & & \multicolumn{3}{|c|}{ 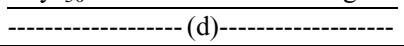 } & & \\
\hline Nontreated & - & 29 & 24 & 33 & 0.54 & 93 \\
\hline Prodiamine ${ }^{\mathrm{y}}$ & 0.59 & 45 & 39 & 52 & 0.54 & 88 \\
\hline Pendimethalin ${ }^{y}$ & 1.66 & 39 & 34 & 44 & 0.61 & 95 \\
\hline Dithiopyr $^{\mathrm{y}}$ & 0.56 & 39 & 34 & 43 & 0.64 & 84 \\
\hline Atrazine & 1.12 & 35 & 31 & 40 & 0.61 & 79 \\
\hline Simazine $^{y}$ & 2.24 & 42 & 37 & 48 & 0.63 & 81 \\
\hline $\begin{array}{l}\text { Atrazine }+ \\
\quad S \text {-metolachlor }\end{array}$ & $1.12+0.86$ & 51 & 44 & 60 & 0.58 & 78 \\
\hline$S$-metolachlor ${ }^{\mathrm{y}}$ & 2.78 & 48 & 42 & 55 & 0.60 & 81 \\
\hline Oxadiazon G & 2.24 & 26 & 23 & 29 & 0.72 & 100 \\
\hline Oxadiazon WSPy & 2.24 & 101 & 67 & 152 & 0.38 & 83 \\
\hline Flumioxazin ${ }^{y}$ & 0.29 & 40 & 35 & 46 & 0.58 & 82 \\
\hline Indaziflam ${ }^{\mathrm{y}}$ & 0.03 & 153 & 62 & 375 & 0.16 & 82 \\
\hline
\end{tabular}

${ }^{\mathrm{z}}$ Maximum cover achieved during the course of the experiment $(\approx 70 \mathrm{~d})$.

${ }^{y}$ Herbicide treatments that increased days to reach $50 \%$ hybrid bermudagrass cover compared with the nontreated. Differences between regression estimates were based on predicted $95 \%$ confidence intervals (CI)

$\mathrm{G}=$ granular; WSP $=$ water-soluble powder.

Table 3. Effects of preemergence herbicide applications on hybrid bermudagrass root mass 6 and $10 \mathrm{WAT}$.

\begin{tabular}{|c|c|c|c|c|}
\hline \multirow[b]{3}{*}{ Herbicide } & \multirow[b]{3}{*}{ Rate (kg a.i./ha) } & \multicolumn{3}{|c|}{ Dry mass } \\
\hline & & $6 \mathrm{WAT}^{\mathrm{z}}$ & $10 \mathrm{WAT}^{\mathrm{y}}$ & $10 \mathrm{WAT}^{\mathrm{y}}$ \\
\hline & & \multicolumn{3}{|c|}{ - } \\
\hline Nontreated & - & $0.304 \mathrm{a}^{\mathrm{x}}$ & $0.704 \mathrm{a}$ & $0.861 \mathrm{bc}$ \\
\hline Prodiamine & 0.59 & $0.115 \mathrm{bcd}$ & $0.268 \mathrm{~b}$ & 0.293 ef \\
\hline Pendimethalin & 1.66 & $0.182 \mathrm{~b}$ & $0.404 \mathrm{~b}$ & 0.334 ef \\
\hline Dithiopyr & 0.56 & $0.160 \mathrm{bc}$ & $0.316 \mathrm{~b}$ & $0.480 \mathrm{cdef}$ \\
\hline Atrazine & 1.12 & $0.169 \mathrm{bc}$ & $0.225 \mathrm{~b}$ & $1.091 \mathrm{ab}$ \\
\hline Simazine & 2.24 & $0.146 \mathrm{bcd}$ & $0.258 \mathrm{~b}$ & $0.405 \mathrm{def}$ \\
\hline Atrazine $+S$-metolachlor & $1.12+0.86$ & $0.071 \mathrm{~cd}$ & $0.259 \mathrm{~b}$ & 0.394 def \\
\hline$S$-metolachlor & 2.78 & $0.141 \mathrm{bcd}$ & $0.219 \mathrm{~b}$ & $0.667 \mathrm{cde}$ \\
\hline Oxadiazon $\mathrm{G}$ & 2.24 & $0.178 \mathrm{~b}$ & $0.190 \mathrm{~b}$ & $0.736 \mathrm{bcd}$ \\
\hline Oxadiazon WSP & 2.24 & $0.150 \mathrm{bcd}$ & $0.265 \mathrm{~b}$ & $0.379 \mathrm{def}$ \\
\hline Flumioxazin & 0.29 & $0.134 \mathrm{bcd}$ & $0.244 \mathrm{~b}$ & $1.437 \mathrm{a}$ \\
\hline Indaziflam & 0.03 & $0.044 \mathrm{~d}$ & $0.235 \mathrm{~b}$ & $0.154 \mathrm{f}$ \\
\hline $\operatorname{LSD}_{0.05}$ & - & 0.106 & 0.246 & 0.388 \\
\hline
\end{tabular}

${ }^{\mathrm{z}}$ Treatment effects on root mass were compared within each harvest date.

${ }^{\mathrm{y}}$ Run-by-treatment interaction was significant for the dry root mass data of roots harvested 10 WAT Therefore, runs are presented separately for the 10 WAT dry root mass data.

${ }^{x}$ Means followed by the same letter in a column are not significantly different.

WAT = weeks after treatment; LSD = least significant difference; $\mathrm{G}=$ granular; $\mathrm{WSP}=$ water-soluble powder. 


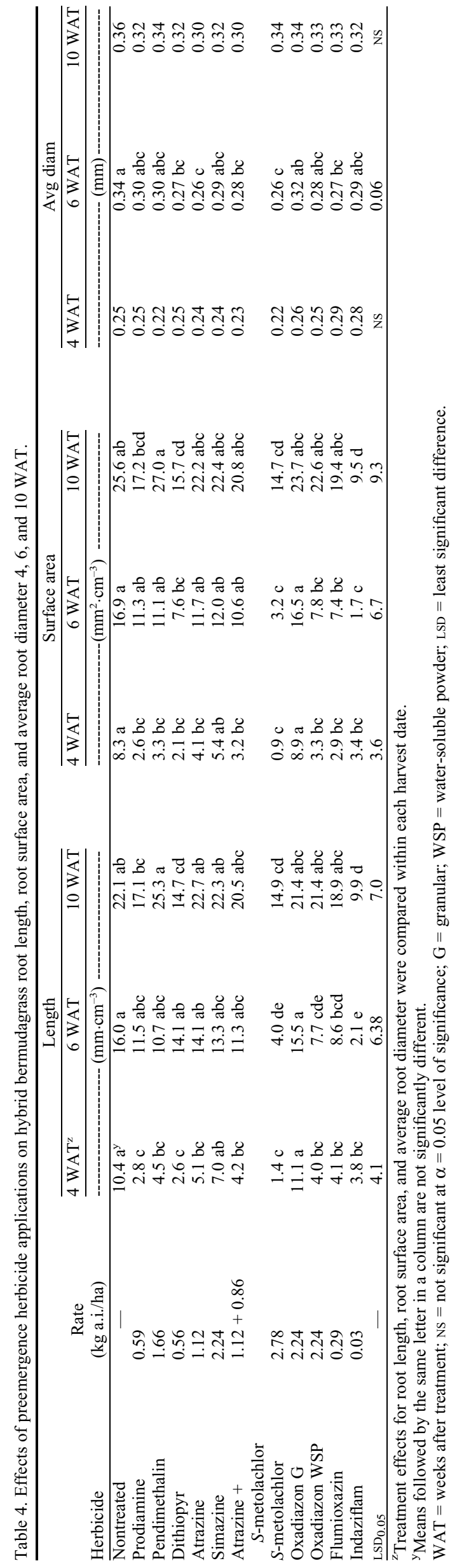

alone, liquid applied oxadiazon, flumioxazin, and indaziflam reduced root length when compared with the nontreated. Dithiopyr, $S$-metolachlor alone, and indaziflam were the only herbicide treatments that reduced root length compared with the nontreated when harvested 10 WAT.

Root surface area. Root surface area reductions were comparable to the previously discussed root lengths (Table 4). At 4 WAT, only simazine and granular applied oxadiazon did not reduce root surface area when compared with the nontreated. Dithiopyr, $S$-metolachlor alone, liquid applied oxadiazon, flumioxazin, and indaziflam reduced root surface area compared with the nontreated when harvested 6 WAT; however, dithiopyr, $S$-metolachlor alone and indaziflam were the only herbicide treatments that reduced root surface area compared with the nontreated when harvested 10 WAT.

Root average diameter. The only harvest date that showed significant differences in average root diameter was 6 WAT (Table 4). Dithiopyr, atrazine, atrazine $+S$-metolachlor, $S$-metolachlor alone, and flumioxazin reduced the average root diameter compared with the nontreated when harvested 6 WAT; however, by 10 WAT, there were no differences among treatments in average root diameter.

Carbohydrate analysis. Pooled results of the carbohydrate analysis across runs are presented separately by harvest date. Further breakdown of amounts of sucrose, glucose, and fructose within the $0.05 \mathrm{~g}$ of dry root matter are presented in Table 5 along with the mean separations for each carbohydrate.

Pendimethalin increased sucrose levels within the roots when compared with the nontreated when harvested 6 WAT. However, by 10 WAT, no differences in the amount of sucrose within the roots were detected between the herbicide treatments and the nontreated. Pendimethalin also reduced the level of glucose compared with the nontreated when harvested 6 WAT, which suggests a possible transformation of glucose to sucrose within the roots. However, by 10 WAT, no differences in the amount of glucose within the roots were detected among herbicide treatments compared with the nontreated. No differences were detected in the amount of fructose within the roots when harvested 6 WAT. However, prodiamine reduced the amount of fructose when compared with the nontreated when harvested at 10 WAT. No differences were detected in TNSC in either run of the experiment

Previous research is lacking on the effect of herbicide applications on nonstructural carbohydrates of turfgrass shoot and root tissue; however, several studies have demonstrated that environmental stress caused by high temperature, which may be a source of imbalance between photosynthesis and respiration, decreases nonstructural carbohydrate contents in the root tissue (Huang and Gao, 2000; Xu and Huang, 2000, 2003). In the present study, applications of pendimethalin increased sucrose concentrations within the 


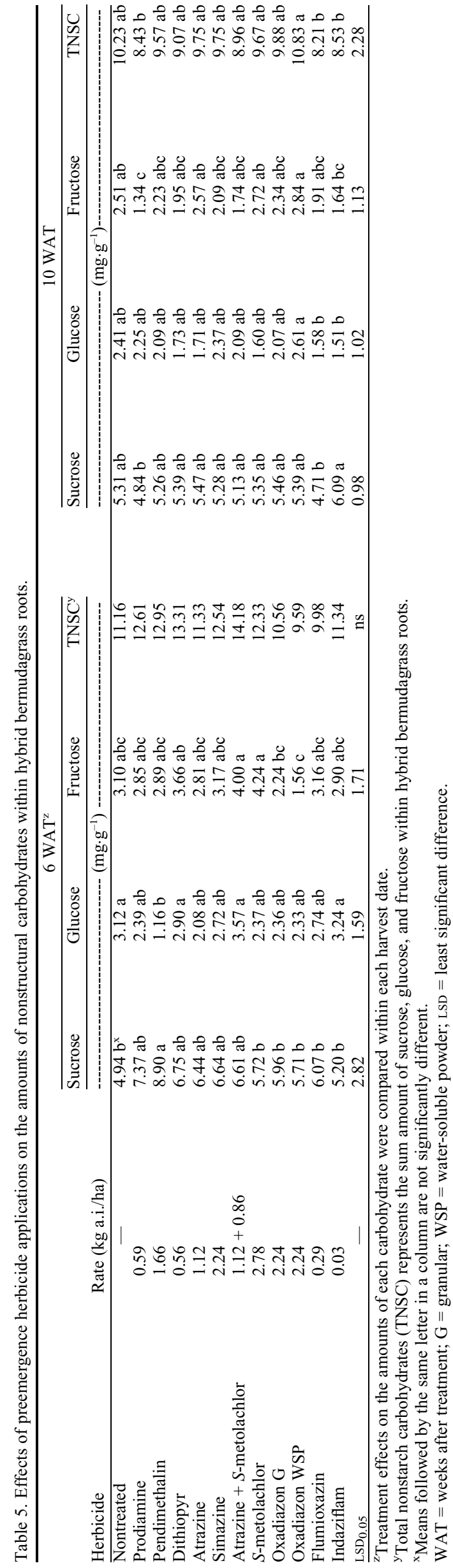

root tissue $6 \mathrm{WAT}$, but sucrose declined 10 WAT. Stress caused by pendimethalin and prodiamine applications to hybrid bermudagrass in the present study may have caused a stress response leading to the direct decrease in glucose and fructose and subsequent increase in sucrose concentrations in root tissue when compared with the nontreated.

Overall, dithiopyr, prodiamine, pendimethalin, atrazine $+S$-metolachlor, $S$-metolachlor alone, liquid applied oxadiazon, and flumioxazin most severely affected hybrid bermudagrass roots and increased time to reach $50 \%$ cover. Results due to the granular application of oxadiazon are in agreement with previous research that suggests oxadiazon is relatively safe on hybrid bermudagrass rooting (Bingham and Hall, 1985; Bingham and Schmidt, 1983; Fishel and Coats, 1994). However, there were significant differences in days to reach $50 \%$ hybrid bermudagrass cover between the granular and liquid applied formulations of oxadiazon measuring 26 and $101 \mathrm{~d}$, respectively. Authors are aware that oxadiazon applied as a liquid broadcast is not recommended on nondormant bermudagrass without immediate irrigation following the application of the herbicide. Therefore, the negative effects on grow-in and root architecture observed from liquid applied oxadiazon is likely due to foliar injury rather than soil activity.

Effects of prodiamine on hybrid bermudagrass cover were similar to those of Brosnan et al. (2014), who reported similar reductions from prodiamine and pendimethalin compared with a nontreated. Fagerness et al. (2002) also reported reduced hybrid bermudagrass establishment by as much as $25 \%$ after fall applications of prodiamine at $1.1 \mathrm{~kg} \cdot \mathrm{ha}^{-1}$. The observed effects of pendimethalin and dithiopyr in this study also support similar studies that demonstrated reduced establishment after applications of these herbicides (Boyd and Baird, 1997; Fagerness et al., 2002). However, reduced rates of these herbicides may be comparably safe to other herbicides; thus, future research should take into account weed emergence, competition with sod establishment, and required postemergence applications to control escaped weeds.

Based on the results of the present study, applications of indaziflam and $S$-metolachlor are not safe on newly sprigged hybrid bermudagrass and support current labeling, which limits the use of these herbicides until hybrid bermudagrass is fully established (Bayer Environmental Sciences, 2012; Syngenta Crop Protection, 2003). Effects of indaziflam on hybrid bermudagrass support similar studies that demonstrated reductions in establishment and recovery. Beck et al. (2013) observed significant reductions in bermudagrass recovery ( $13 \%$ to $14 \%)$ from spring dead spot after applications of indaziflam. In addition, Jones et al. (2015) observed significant increases in hybrid bermudagrass injury (curling of new growth, reddening of leaf tissue, and necrosis) and reduced visual 
root mass compared with oxadiazon and prodiamine. However, Jones et al. (2013) determined that soil type and rooting depth can affect hybrid bermudagrass injury caused by indaziflam. Indaziflam injury was greatest when hybrid bermudagrass was grown in a sand root zone with no organic matter ( $23 \%$ to $48 \%$ ).

The authors are aware of instances where flumioxazin has been used in sod production, although not during sprigged establishment. Flumioxazin was included because of its shared mode of action with oxadiazon [both protoporphyrinogen oxidase (PROTOX) inhibitors]. PROTOX inhibitors are novel in that they control certain broadleaf and grassy weeds resistant to mitotic-inhibiting herbicides (Valent U.S.A. Corporation, 2015).

These results should assist sod farmers and other turf managers with developing preemergence herbicide weed control programs that limit the injury to newly established hybrid bermudagrass. Future research should evaluate the effects of various rates of these same preemergence herbicides on hybrid bermudagrass and the effects of these preemergence herbicides on sod tensile strength at harvest.

\section{Literature Cited}

Barickman, T.C., D.A. Kopsell, and C.E. Sams. 2017. Abscisic acid improves tomato fruit quality by increasing soluble sugar concentrations. J. Plant Nutr. 40:964-973.

Bayer Environmental Sciences. 2012. Specticle Flo herbicide label. Bayer publication No. 8004419B. Bayer Environmental Sciences, Triangle Park, NC.

Beck, L.L., T. Cooper, A.J. Hephner, C.M. Straw, and G.M. Henry. 2013. Effect of preemergence herbicides on the recovery of bermudagrass from spring dead spot Appl. Turf Sci. doi:10.1094/ATS-2013-0328-01-RS.

Bingham, S.W. and J.R. Hall. 1985. Effects of herbicides on bermudagrass (Cynodon spp.) sprig establishment. Weed Technol. 33:253257.

Bingham, S.W. and R.E. Schmidt. 1983. Turfgrass establishment after application of preemergence herbicides. Agron. J. 75:923-926.

Boyd, J.W. and J.H. Baird. 1997. Herbicide effects on sprig establishment of Zoysia japonica cv. El Toro and Cynodon dactylon $\times C$. transvaalensis cv. 'Midlawn'. Intl. Turfgrass Soc. Res. J. 8:1025-1032.

Brosnan, J.T., G.K. Breeden, A.W. Thoms, and J.C. Sorochan. 2014. Effects of preemergence herbicides on the establishment rate and tensile strength of hybrid bermudagrass sod. Weed Technol. 28:206-212.

Fagerness, M.J., F.H. Yelverton, and R.J. Cooper. 2002. Bermudagrass [Cynodon dactylon (L.) Pers.] and zoysiagrass (Zoysia japonica) establishment after preemergence herbicide applications. Weed Technol. 16:597-602.

Fishel, F.M. and G.E. Coats. 1994. Bermudagrass (Cynodon dactylon) sod rooting as influenced by herbicides. Weed Technol. 8:46-49.

Huang, B. and H. Gao. 2000. Growth and carbohydrate metabolism of creeping bentgrass cultivars in response to increasing temperatures. Crop Sci. 40:1115-1120.

Hull, R. 1992. Energy relations and carbohydrate partitioning in turfgrass, p. 175-205. In: D.V. Waddington, R.N. Carrow, and R.C. Sherman (eds.). Turfgrass. Amer. Soc. Agron., Madison, WI.

Johnson, B.J. 1996. Reduced rates of preemergence and postemergence herbicides for large crabgrass (Digitaria sanguinalis) and goosegrass (Eleusine indica) control in bermudagrass (Cynodon dactylon). Weed Sci. 44:585-590.

Jones, P.A., J.T. Brosnan, D.A. Kopsell, G.R. Armel, and G.K. Breeden. 2015. Preemergence herbicides affect hybrid bermudagrass nutrient content. J. Plant Nutr. 38:177-188.

Jones, P.A., J.T. Brosnan, D.A. Kopsell, and G.K. Breeden. 2013. Soil type and rooting depth affect hybrid bermudagrass injury with preemergence herbicides. Crop Sci. 53:660-665.

Karcher, D.E. and M.D. Richardson. 2003. Quantifying turfgrass color using digital image analysis. Crop Sci. 43:943-951.

Macolino, S., M. Serena, B. Leinauer, and U. Ziliotto. 2010. Preliminary findings on the cor- relation between water-soluble carbohydrate content in stolons and first year green-up of seeded bermudagrass cultivars. HortTechnology 20:758-763.

McCalla, J.B., Jr., M. Richardson, D. Karcher, J. Landreth, and A. Patton. 2008. Sod production utilizing an improved seeded bermudagrass cultivar. Appl. Turf Sci. doi:10.1094/ATS2008-0118-01-RS/.

McCullough, P.E., B.M. Schwartz, T. Grey, and T. Webster. 2012. Preemergence herbicides influence sprig establishment of 'TifEagle' hybrid bermudagrass. Weed Technol. 36:300-303.

Richardson, M.D., D.E. Karcher, and L.C. Purcell. 2001. Quantifying turfgrass cover using digital image analysis. Crop Sci. 41:1884-1888.

Schiavon, M., S. Macolino, B. Leinauer, and U. Ziliotto. 2016. Seasonal changes in carbohydrate and protein content of seeded bermudagrasses and their effect on spring green-up. J. Agron. 202:151-160.

Sharpe, S.S., R. Dickens, and D.L. Turner. 1989. Herbicide effects on tensile strength and rooting of bermudagrass (Cynodon dactylon) sod. Weed Technol. 3:353-357.

Sheffer, K.M., T.L. Watschke, and J.M. Duich. 1979. Carbohydrate sampling in Kentucky bluegrass turf. Agron. J. 71:301-304.

Syngenta Crop Protection. 2003. Pennant Magnum herbicide label. Syngenta Crop Protection, Greensboro, NC.

Valent U.S.A. Corporation. 2015. SureGuard herbicide label. Valent U.S.A. Corporation, Walnut Creek, CA.

Vaughn, K.C. and M.A. Vaughn. 1990. Structural and biochemical characterization of dinitroanilineresistance Eleusine. Managing resistance to agrochemicals Amer. Chem. Soc. 25:364-375.

Weber, J.B. 1990. Behavior of dinitroaniline herbicides in soil. Weed Technol. 4:394-406.

White, L.M. 1973. Carbohydrate reserves of grasses: A review. J. Range Mgt. 26:13-18.

Xu, Q. and B. Huang. 2000. Effect of differential air and soil temperature on carbohydrate metabolism in creeping bentgrass. Crop Sci. 40: 1368-1374.

Xu, Q. and B. Huang. 2003. Seasonal changes in carbohydrate accumulation for two creeping bentgrass cultivars. Crop Sci. 43:266-271. 